\title{
Immunological system status and the appearance of respiratory system disturbances in thymectomized patients
}

\section{Paweł Krawczyk $^{1}$, Marta Adamczyk-Korbel ${ }^{1}$, Robert Kieszko ${ }^{1}$, Elżbieta Korobowicz ${ }^{2}$ and Janusz Milanowski ${ }^{1}$}

${ }^{1}$ Department of Pneumonology, Oncology, and Allergology, Medical University of Lublin, Poland

${ }^{2}$ Department of Pathomorphology, Medical University of Lublin, Poland

Received: 2006.01.02, Accepted: 2006.10.06, Published online first: 2007.02.02

\begin{abstract}
Introduction: Adult-onset thymoma may be responsible for several diseases, such as pure red cell aplasia, myasthenia gravis, and immunodeficiency (Good's syndrome). Thymectomy does not always improve the patient's condition, and may even produce additional symptoms. Its pathogenesis is still not entirely understood, but autoimmunological processes and bone marrow defect are the most frequently suggested.

Materials and Methods: Eleven patients (mean age: $56.2 \pm 15.5$ years) were analyzed 6 months to 10 years after thymectomy due to thymoma as were 25 healthy persons serving as controls. Enzyme-linked immunosorbent assay (ELISA) and flow cytometry techniques were used to evaluate the immunological status of the subjects.

Results: Good's syndrome was diagnosed in one patient, 4 subjects suffered from myasthenia gravis, and recurrent infections of upper and lower respiratory tract appeared in 9 patients. The immunological analyses (ELISA and flow cytometry) revealed a significantly lower IgG level $(p<0.05)$, percentage of peripheral blood B lymphocytes $(p<0.0005)$, and CD4:CD8 ratio $(\mathrm{p}<0.05)$ in thymectomized patients compared with the healthy controls. The percentages of $\mathrm{CD} 4^{+}$and $\mathrm{CD} 8^{+} \mathrm{T}$ lymphocytes expressing CD28 antigen were significantly lower in thymectomized patients than in healthy subjects ( $p<0.005$ and $\mathrm{p}<0.01$, respectively). The percentage of naïve $\mathrm{T}$ helper lymphocytes was significantly lower in the patients than in the control group $(\mathrm{p}<0.05)$.

Conclusions: Immunodeficiency and recurrent infections may be the first symptoms of immunological disturbances after thymectomy in adults. It is suggested that regular medical monitoring of these patients is important in preventing further complications, which may result in irreversible lung tissue destruction.
\end{abstract}

Key words: thymectomy, immunodeficiency, respiratory infections.

Abbreviations: AChR - acetylocholine receptor, CVID - common variable immunodeficiency, ELISA - enzyme-linked immunosorbent assay, FEF25, FEF50, FEF75 - forced expiratory flow at 25, 50, and 75\% of vital capacity, FEV1 - one-second forced expiratory volume, GS - Good's syndrome, MG - myasthenia gravis, PBL - peripheral blood lymphocyte, PFT pulmonary function test, PRCA - pure red cell aplasia, TCR - T cell receptor, Th - T-helper, TRECs - TCR $\delta$ excision circle, VC - vital capacity.

Corresponding author: Paweł Krawczyk, M.D. Ph.D., Department of Pneumonology, Oncology, and Allergology, Medical University of Lublin, Jaczewskiego 8, 20-950 Lublin, Poland, tel.: +48 81 742-52-46, fax: +48 81 740-04-02, e-mail: pulm.dept@am.lublin.pl

\section{INTRODUCTION}

For centuries the thymus remained an enigmatic organ of unknown function. The first demonstration of its crucial role in establishing the development of a normal immune system was provided in 1961 when it was shown that mice thymectomized immediately after birth had poorly developed lymphoid tissue, impaired immune responses, and an inordinate susceptibility to recurrent infections [11]. The role of thymus in T cell development and in the postnatal lymphocyte developmental stages is currently being investigated. The precursors that give rise to $\mathrm{T}$ cells leave the bone marrow and migrate to the thymus for their differentiation. $\mathrm{T}$ cell development in 
the thymus is divided into two main stages. The first is independent of the $\mathrm{T}$ cell receptor (TCR), while the second is completely dependent on the TCR and its interaction. Immature thymocytes in the first stage do not express any definitive T cell markers. These are CD4 and CD8 double-negative early thymocytes. These cells migrate through the thymic cortex, proliferating extensively and acquiring new surface markers. The first intracellular TCR proteins, products of successful TCR gene rearrangement, are seen at the end of the first developmental stage. Cells that succeed in expressing TCR $\gamma$ and $\mathrm{TCR} \delta$ proteins develop into mature TCR $\gamma \delta$. If they are successful in TCR $\beta$ rearrangement, the TCR $\beta^{+}$cells are rewarded by proliferation and differentiation into CD4 and $\mathrm{CD} 8$ double-positive cells. These cells, the precursors of conventional TCR $\alpha \beta$ T lymphocytes, go on to rearrange their TCR $\alpha$ genes and undergo positive and negative selection for self/non-self discrimination through the engagement of TCR with peptide present in a major histocompatibility complex on antigen-presenting cells. Mature thymocytes differentiate into CD4 or CD8 single-positive T cells. After positive selection and maturation, T lymphocytes finally exit the thymus to take up their roles in the immune system [17].

The destruction of the thymic structure in the course of thymoma is responsible for immunological disturbances in the selection and maturation of T cells. Adult onset of thymoma may be the cause of several autoimmunological diseases, such as pure red cell aplasia (PRCA), myasthenia gravis (MG), alopecia areata, and Sjögren's syndrome [8]. Good's syndrome (GS), first described in 1954, is a rare condition characterized by recurrent infection in the course of thymoma and immunodeficiency [3]. A typical patient affected by GS is in their fifties to seventies and develops recurrent bronchitis, sinusitis, or pneumonia which may be complicated with bronchiectasis. Systemic symptoms such as weight loss, fatigue, chronic diarrhea, and dermatitis are common. Immunodeficiency in GS is characterized by a low number of peripheral blood B cells, or even their absence, and hypogammaglobulinemia. These disturbances may be derivative of defects in cell-mediated immunity, manifested by $\mathrm{CD} 4{ }^{+} \mathrm{T}$-lymphopenia and an inverted CD4:CD8 ratio. Thymectomy does not always improve the patient's condition, and may even produce additional symptoms. The pathogenesis of the phenomenon is still not entirely understood [22].

The aim of the study was to determine immunological disturbances in patients after thymectomy. We searched for evidence that removal of the thymus may be responsible for several abnormalities of the respiratory system. We suggest that immunodeficiency and respiratory system disturbances may be common in thymectomized patients.

\section{MATERIALS AND METHODS}

We analyzed four men and seven women (mean age: $56.2 \pm 15.5$ years, range: $27-76$ years) 6 months to 10 years (mean: $60.4 \pm 35.2$ months) after thymectomy due to thymoma. Since then, tumor recurrence had not been detected in any case. Appropriate treatment (chemotherapy and/or radiotherapy) was applied only in patients with malignant thymoma.

Thymoma, the most common primary tumor of the anterior mediatsinum, is pathologically an epithelial neoplasm characterized by an admixture of epithelial cells and mature lymphocytes [21]. The thymomas were classified according to the recent World Health Organization (WHO) classification as WHO type A and AB thymomas (medullary and mixed thymomas), type B thymomas (predominantly cortical and cortical thymomas and well-differentiated thymic carcinomas), and type $\mathrm{C}$ thymomas (category II malignant thymomas) [14].

The diagnosis of respiratory infection susceptibility was based on patient history and a physical examination, routine serum biochemical and hematological tests, chest and sinus X-rays, pulmonary function tests (PFTs), and a sputum microbiological analysis. Lung function parameters, including the one-second forced expiratory volume (FEV1), vital capacity (VC), and forced expiratory flow at $25 \%, 50 \%$, and $75 \%$ of $\mathrm{VC}$, were measured with a pneumotachograph (ABC-Med, Kraków, Poland). The values obtained were expressed as percentages of the predicted normal values. FEV1\%VC was also evaluated. Airflow obstruction was defined as FEV1\%VC below 0.7 with VC above $80 \%$. Restriction was defined as VC below $80 \%$ and FEV1 below $80 \%$ with FEV1\%VC above 0.7 . Small airflow obstruction was defined as FEF50 below $60 \%$ with FEV1\%VC above 0.7 and VC and FEV1 above $80 \%$. Mixed-type PFT disturbances was defined as FEV1\%VC below $0.7, \mathrm{VC}$ and FEV1 below $80 \%$.

The diagnosis of MG was based on clinical features, decrement testing on $3-\mathrm{Hz}$ serial stimulation, and the detection of anti-acetylocholine receptor (AchR) autoantibodies. Good's syndrome was diagnosed based on clinical symptoms as well as measurements of the gammaglobulin level and the peripheral blood B cell percentage and count.

Protein electrophoresis, a lymphocyte subtype cytometric analysis, and the ELISA for serum immunoglobulin level analysis were performed to detect immunological disturbances. Three-color flow cytometry was used to establish peripheral blood lymphocyte (PBL) subtypes. The following directly conjugated monoclonal antibodies were used: Simultest (Becton Dickinson), mouse anti-human CD4 FITC, CD8 PerCP, CD28 PE, CD45RO $\mathrm{PE}$, and CD45RA PE (Becton Dickinson, Pharmingen). Immunnofluorescent staining was performed according to the manufacturer's protocol using Lysing Solution (Becton Dickinson) for erythrocyte elimination. Cells were collected in a FACS Calibur flow cytometer (Becton Dickinson) and their phenotype analyzed using Cell Quest Software. The results of steroid-treated patients were not significantly different in any of the assays. The tests were performed before immunoglobulin supplementation in the patient with GS. 
Blood samples from 25 healthy individuals (mean age: $49.2 \pm 10.7$ years, range: $23-66$ years) matched for sex and age were studied as controls. The study was performed with the approval of the Ethics Committee of the Medical University of Lublin.

Both descriptive and analytical statistical methods were used to analyze the data. Statistical analysis was performed using the non-parametric Mann-Whitney U-test and Spearman's correlation test as well as Statistica 5.0 software. The statistical tests used a two-sided level of significance of 0.05 .

\section{RESULTS}

The clinical data are summarized in Table 1. Of the thymectomized patients, $36.4 \%(n=4)$ suffered from MG. The symptoms of myasthenia occurred prior to thymectomy in two patients. Myasthenia appeared three months and one year after thymectomy in the two other patients. Recurring or acute infections of the upper and lower respiratory tract appeared in $81.8 \%$ $(n=9)$ of the thymectomized patients. Chronic diarrhea following respiratory infections was seen in two patients. Good's syndrome was diagnosed in one patient examined.

Thickening of the maxillary sinus mucosa and a reduction in sinus airspace was ascertained in 5 thymectomized patients. In the patient with GS, these coexisted with infiltration in the superior and middle fields of the left lung and with pleural adhesions at the left lung base, as could be seen in the chest radiograph. Bilateral ground-glass opacities and diffuse areas of condensation as well as infiltration in the lingual of the left lung with mediastinal displacement dominated in the computed tomography chest scan of this patient. In another patient, bilateral pleural effusion and pericardial effusion were showed in the chest X-ray. In all patients, the features of the thymectomy were seen in the chest radiograph.

For all the examined patients the mean spirometric values were in the normal range $\left(\mathrm{FEV}_{1} 73.2 \pm 22.33 \%\right.$, VC $86.0 \pm 22.0 \%, \quad \mathrm{FEV}_{1} / \mathrm{VC} \quad 0.87 \pm 0.18, \quad \mathrm{FEF} 25$ $76.8 \pm 38.93 \%, \quad$ FEF50 $68.3 \pm 35.78 \%$, FEF75 $68.2 \pm 34.78 \%)$. We found 5 patients with restriction, including two subjects with MG and one patient with GS. In one patient, PFT disturbances of the obstruction type were determined. Two subjects were affected by small airway disease.

Microbiological analysis of the sputum samples was performed in 6 patients. The cultures of sputum yielded Streptoccocus viridans (5 patients), Candida sp. (6 patients), Streptococcus alfa (1 patient), Neisseria sp. (3 patients), Citrobacter koseri (1 patient), Citrobacter braaki (the GS patient), Haemophilus parainfluenze (2 patients), and Escherichia coli (1 patient). Tests for HIV infection were negative.

The mean results of the routine hematological and biochemical tests of the thymectomized patients did not differ significantly from those of the healthy controls, with the exception of the total number and the subtypes of peripheral blood leukocytes. The total number of leukocytes and granulocytes was significantly higher $(\mathrm{p}<0.05)$ in the thymectomized patients than in the control subjects. The number and percentage of peripheral blood eosinophils were significantly lower $(\mathrm{p}<0.05$ and $\mathrm{p}<0.0005$, respectively) in the examined patients ( $89 \pm 87$ cells $/ \mu \mathrm{l}$ and $0.84 \pm 0.96 \%$, respectively) than in the healthy controls $(191 \pm 149$ cells $/ \mu$ l and $2.46 \pm 1.05 \%$, respectively). Laboratory tests of the GS patient demonstrated a low level of total serum protein $(4.9 \mathrm{~g} / \mathrm{dl})$ due to a reduction in the percentage and the level of betaand gammaglobulins $(2.9 \%, 0.16 \mathrm{~g} / \mathrm{dl}$ and $3.3 \%, 0.18$ $\mathrm{g} / \mathrm{dl}$, respectively).

For all the thymectomized patients, the mean level of serum immunoglobulin was within the normal range. Lack of immunoglobulins was characteristic of the patient with GS. The mean concentration of $\mathrm{IgG}$ was significantly lower and the level of $\operatorname{IgM}$ significantly higher in the thymectomized patients than in the healthy subjects $(\mathrm{p}<0.05$; Tables 2 and 3$)$.

The percentage and number of peripheral blood B lymphocytes (CD19+ cells) was significantly lower $(\mathrm{p}<0.0005)$ and the percentage of $\mathrm{T}$ lymphocytes $\left(\mathrm{CD}^{+}\right.$cells $)$significantly higher $(\mathrm{p}<0.01)$ in thymectomized patients than in the healthy subjects. Cytometric analysis revealed a higher percentage of cytotoxic-suppressor $\mathrm{T}$ lymphocytes and a lower CD4:CD8 ratio in the examined patients than in the control group (Tables 2 and 4). The results obtained for the GS patient were characterized by the almost total absence of B lymphocytes $(0.47 \%, 12$ cells $/ \mu 1)$ and the presence of CD4 and CD8 double-positive cells (16.04\%, 410 cells/ $\mu$ l). Patients nos. 2-9 had low B cell percentages and patients nos. 4, 5, 8, and 10 had inverted CD4:CD8 ratios (Table 1), but without full-symptomatic GS and without hypogammaglobulinemia.

In the thymectomized patients, the percentage of $\mathrm{CD}^{+}$cells correlated significantly and positively with the level of IgG $(\mathrm{R}=0.697, \mathrm{p}<0.05)$. We found a negative correlation between the percentage of $\mathrm{CD}^{+}$cells and the concentration of $\operatorname{IgM}(\mathrm{R}=0.624, \mathrm{p}=0.054)$. The CD4:CD8 ratio correlated positively with the level of $\operatorname{IgG}$ and $\operatorname{IgM}(\mathrm{R}=0.612, \mathrm{R}=0.624$ and $\mathrm{p}=0.06, \mathrm{p}=0.054$, respectively). There were no such correlations in the healthy subjects.

The percentage of memory $\mathrm{T}$ cells was similar in both groups. The percentages of $\mathrm{CD}^{+}$and $\mathrm{CD}^{+}$ $\mathrm{T}$ lymphocytes expressing CD28 antigen were significantly lower in the thymectomized patients than in the healthy subjects $(\mathrm{p}<0.005$ and $\mathrm{p}<0.01$, respectively). The percentage of naïve T-helper (Th) lymphocytes was significantly lower in the examined patients than in the control group (Fig. 1). The thymectomized patients with $\mathrm{MG}$ showed a slightly higher percentage of naïve $\mathrm{CD} 8^{+}$cells with CD45RA antigen than the patients without MG and the control subjects. The percentage of naïve $\mathrm{CD} 4^{+} \mathrm{T}$ cells was slightly lower in both the MG-positive and the MG- 


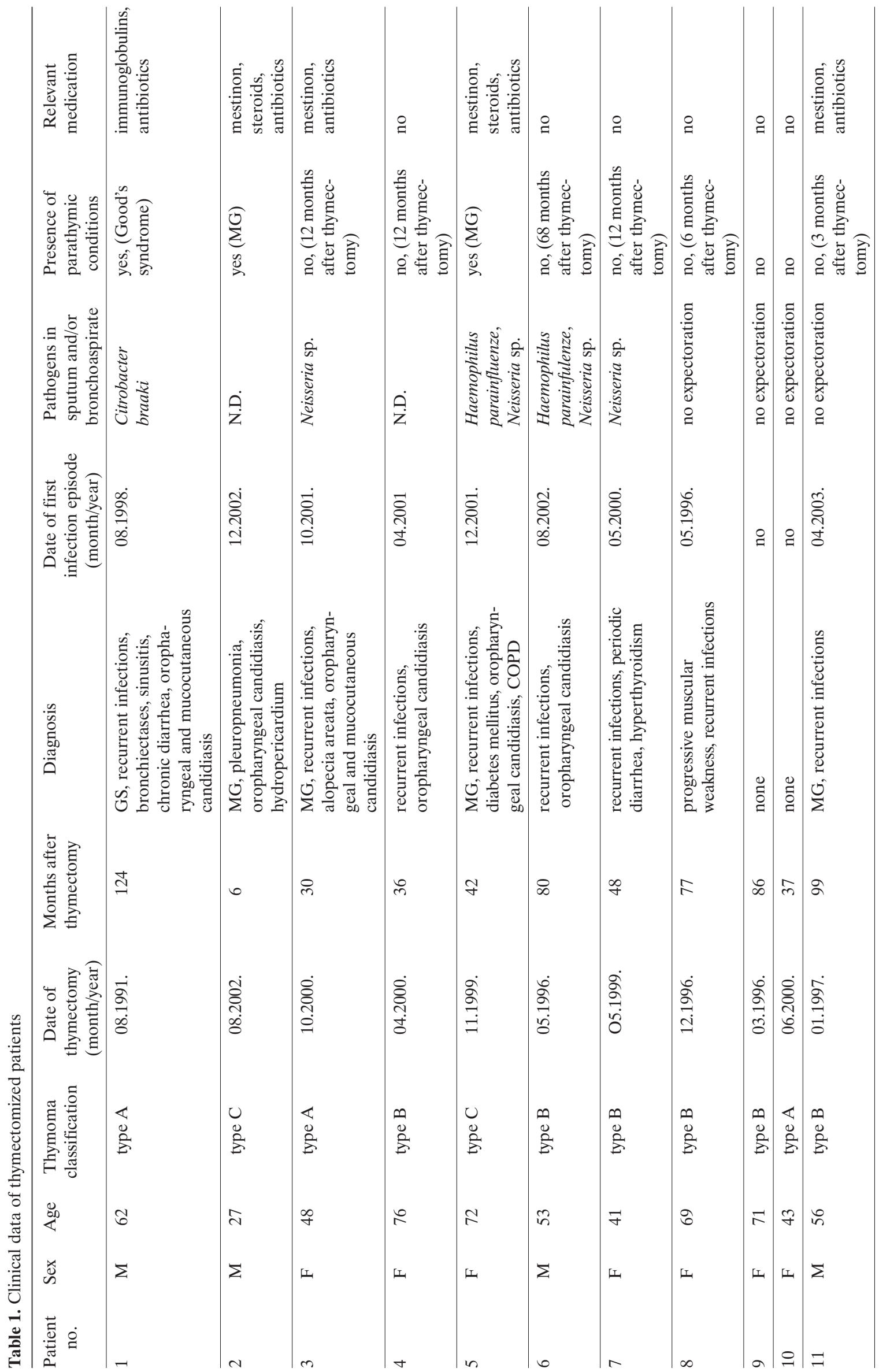


Table 2. Immunological characteristic of thymectomized patients

\begin{tabular}{|c|c|c|c|c|c|c|c|c|c|c|c|}
\hline $\begin{array}{l}\text { Patient } \\
\text { no. }\end{array}$ & $\begin{array}{l}\text { Leuko- } \\
\text { cyte } \\
\text { (cells/ } \\
\mathrm{mm}^{3} \text { ) }\end{array}$ & $\begin{array}{l}\text { Lympho- } \\
\text { cyte } \\
(\%)\end{array}$ & $\begin{array}{c}\mathrm{CD} 19^{+} \\
\text {cells } \\
(\%)\end{array}$ & $\begin{array}{c}\mathrm{CD} 19^{+} \\
\text {cells } \\
(\text { cells/ } \\
\mathrm{mm}^{3} \text { ) }\end{array}$ & $\begin{array}{l}\mathrm{CD}^{+} \\
\text {cells } \\
(\%)\end{array}$ & $\begin{array}{l}\mathrm{CD}^{+} \\
\text {cells } \\
(\text { cells/ } \\
\left.\mathrm{mm}^{3}\right)\end{array}$ & $\begin{array}{l}\mathrm{CD}^{+} \\
\text {cells } \\
(\%)\end{array}$ & $\begin{array}{l}\mathrm{CD}^{+} \\
\text {cells } \\
(\text { cells/ } \\
\left.\mathrm{mm}^{3}\right)\end{array}$ & $\begin{array}{c}\mathrm{IgG} \\
(\mathrm{mg} / \mathrm{dl})\end{array}$ & $\begin{array}{c}\operatorname{IgM} \\
(\mathrm{mg} / \mathrm{dl})\end{array}$ & $\begin{array}{c}\operatorname{IgA} \\
(\mathrm{mg} / \mathrm{dl})\end{array}$ \\
\hline 1 & 5900 & 39.6 & 0.64 & 15 & 26.56 & 620 & 44.42 & 1038 & 9 & 0 & 0 \\
\hline 2 & 12300 & 33.5 & 4.17 & 172 & 37.71 & 1554 & 37.03 & 1526 & 1213 & 305 & 277 \\
\hline 3 & 5700 & 34.1 & 7.73 & 150 & 43.37 & 843 & 33.93 & 660 & 1222 & 181 & 385 \\
\hline 4 & 4700 & 33.1 & 1.12 & 17 & 30.82 & 480 & 58.29 & 907 & 1313 & 205 & 174 \\
\hline 5 & 8000 & 28.6 & 4.38 & 100 & 36.33 & 831 & 52.36 & 1198 & 867 & 176 & 151 \\
\hline 6 & 4400 & 28.3 & 4.07 & 51 & 45.81 & 570 & 41.75 & 520 & 1507 & 111 & 323 \\
\hline 7 & 8000 & 16.1 & 7.75 & 100 & 46.62 & 600 & 33.00 & 425 & 1573 & 488 & 513 \\
\hline 8 & 9300 & 23.8 & 1.85 & 41 & 33.74 & 747 & 52.40 & 1160 & 1464 & 164 & 165 \\
\hline 9 & 8100 & 29.2 & 3.41 & 81 & 51.84 & 1226 & 33.09 & 782 & 1065 & 190 & 118 \\
\hline 10 & 6200 & 25.7 & 18.11 & 288 & 20.17 & 321 & 40.46 & 644 & 1936 & 211 & 409 \\
\hline 11 & 11200 & 17.7 & 19.73 & 391 & 38.87 & 770 & 28.50 & 565 & 1178 & 76 & 149 \\
\hline Mean & 7600 & 28.15 & 6.63 & 127 & 37.44 & 778 & 41.38 & 857 & 1213.4 & 191.5 & 242.2 \\
\hline SD & 2560 & 7.1 & 6.50 & 118 & 9.35 & 347 & 9.58 & 341 & 490.3 & 126.1 & 152.0 \\
\hline
\end{tabular}

Table 3. Immunoglobulin levels in serum of examined subjects

\begin{tabular}{lclcc}
\hline & $\begin{array}{c}\text { Thymectomized } \\
\text { patients }\end{array}$ & $\begin{array}{l}\text { Healthy } \\
\text { subjects }\end{array}$ & $\begin{array}{c}\text { Good's } \\
\text { syndrome } \\
\text { patient }\end{array}$ & $\begin{array}{c}\text { Reference } \\
\text { range }\end{array}$ \\
\hline $\mathrm{IgG}(\mathrm{mg} / \mathrm{dl})$ & $1213.4 \pm 490.3$ & $1623.1 \pm 511$ & 9 & $900-1700$ \\
$\mathrm{IgM}(\mathrm{mg} / \mathrm{dl})$ & $191.5 \pm 126.1$ & $107.5 \pm 81.5$ & 0 & $50-320$ \\
$\mathrm{IgA}(\mathrm{mg} / \mathrm{dl})$ & $242.2 \pm 152.0$ & $259.8 \pm 171.9$ & 0 & $100-490$ \\
\hline
\end{tabular}

Table 4. Subtypes of lymphocytes in peripheral blood of thymectomized patients and healthy subjects

\begin{tabular}{lccccccc}
\hline & $\begin{array}{c}\mathrm{CD} 19^{+} \text {cells } \\
(\%)\end{array}$ & $\begin{array}{c}\mathrm{CD}^{+} \text {cells } \\
(\%)\end{array}$ & $\begin{array}{c}\mathrm{CD}^{+} \text {cells } \\
(\%)\end{array}$ & $\begin{array}{c}\mathrm{CD}^{+} \text {cells } \\
(\%)\end{array}$ & $\begin{array}{c}\mathrm{CD}^{+} / \mathrm{CD}^{+} \\
\text {cells }(\%)\end{array}$ & $\begin{array}{c}\text { CD4:CD8 } \\
\text { ratio }\end{array}$ & $\begin{array}{c}\text { NK cells } \\
(\%)\end{array}$ \\
\hline $\begin{array}{l}\text { Thymectomized } \\
\text { patients }\end{array}$ & $6.63 \pm 4.84$ & $77.79 \pm 12.22$ & $37.44 \pm 9.34$ & $41.38 \pm 8.57$ & $3.08 \pm 4.51$ & $0.93 \pm 0.37$ & $13.39 \pm 5.93$ \\
Healthy subjects & $11.71 \pm 4.37$ & $67.52 \pm 7.69$ & $41.10 \pm 7.60$ & $32.08 \pm 7.48$ & $1.86 \pm 0.91$ & $1.39 \pm 0.53$ & $15.15 \pm 8.79$ \\
\hline
\end{tabular}

negative group of thymectomized patients than in the control group (Table 5).

\section{DISCUSSION}

The human thymus is the central lymphoid organ that provides a specialized microenvironment for maturation and selection for the majority of TCR $\alpha \beta$ T lymphocytes. With increasing age, the lymphatic thymic mass decreases and thymocyte production declines in parallel (thymic involution) [17]. Recent data, and the results of our investigation, suggest, however, that the adult thymus can remain active even late in life, supplying functional $\mathrm{T}$ cells to the periphery.

The appearance of autoimmunological disease and immunodeficiencies in patients suffering from thymoma, and in thymecomized subjects, indicates the important role of the thymus in adults. Myasthenia gravis and PRCA are occasionally associated with thymoma. MG appears in about $20-40 \%$ of patients with thymoma and PRCA develops in about 2-5\% of those patients. On the other hand, thymoma is detected in $10-17 \%$ of patients with MG and in 5-13\% of patients with PRCA [12].

Hypogammaglobulinemia and B-lymphopenia develop in 3-6\% patients with thymoma. According to Tarr et al. [22], reviews of the literature identified 51 reports of infections in GS patients. The infections included recurrent sinopulmonary infection most often developed by Haemophilus influenzae, cytomegalovirus infection, bacteremia, oral or esophageal candidiasis, persistent mucocutaneous candidiasis, chronic diarrhea with documented stool pathogens, urinary tract infections, Pneumocystis carinii pneumonia, tuberculosis, Kaposi's sarcoma, and disseminated varicella. Patients with GS present a spectrum of sinopulmonary infections and pathogens similar to common variable immunodeficiency (CVID). Compared with patients with CVID, opportunistic infections, including severe cytomegalovirus disease, Pneumocytsis carinii pneumonia, and mucocutaneous 

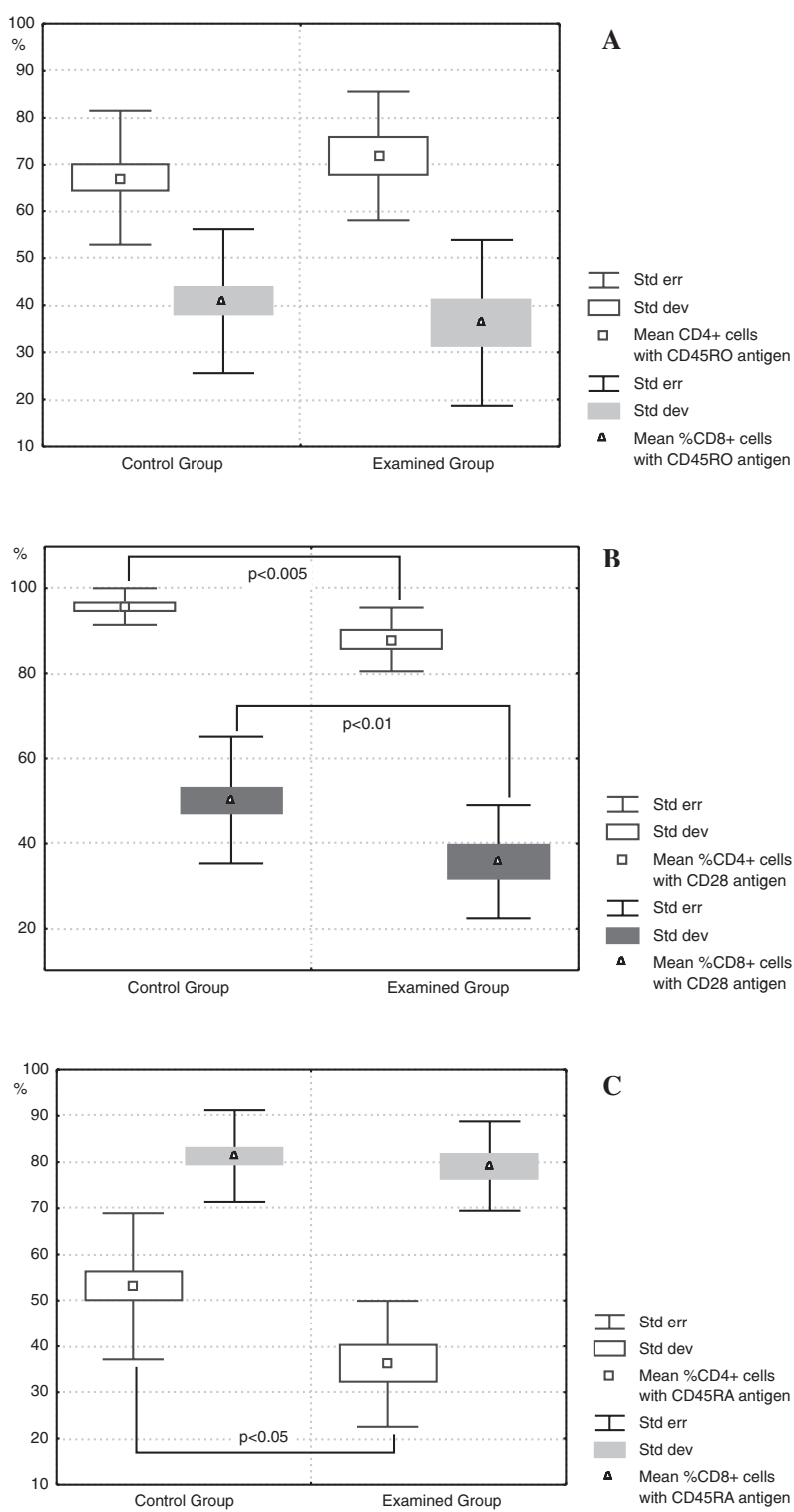

Fig. 1. Phenotype of T-helper $\left(\mathrm{CD}^{+}\right)$and $\mathrm{T}$ cytotoxic-suppressor $\left(\mathrm{CD}^{+}\right)$lymphocytes in peripheral blood of the examined subjects: $\mathbf{A}-$ memory T cells $\left(\mathrm{CD} 45 \mathrm{RO}^{+}\right), \mathbf{B}-\mathrm{CD} 28^{+}$cells, $\mathbf{C}-$ naïve $\mathrm{T}$ cells $\left(\mathrm{CD} 45 \mathrm{RA}^{+}\right)$.

candidiasis, appear to be more common in patients with GS, and patients with GS may have a worse prognosis. The development of bronchiectases was also quite frequent in GS $[13,22]$. In our patients, the pathogens were, in part, normal commensals of the upper respiratory tract. However, the manifestation of characteristic symptoms of the diseases and the appearance of immunological disturbances justified us to diagnose recurrent sinopulmonary infections in 8 patients.

Our data indicate that the occurrence of different disorders connected with the abnormal thymic function may be underestimated and more frequent than other authors supposed. Thymectomy was the only marker that the qualified patients to be in the group examined. Prior to our examination, no immunodeficiency was diagnosed. However, thymoma patients without clinical symptoms of immune deficiency would be a very important control group that should be examined in the future.

We suggest that the removal of the thymus is on a par with the disorganized thymic cortical environment in thymoma in causing recurrent respiratory system infections during immunodeficiency. This hypothesis should be verified in patients undergoing thymectomy for non-neoplastic histology, e.g. MG patients with thymic lymphofollicular hyperplasia. However, we concluded that thymectomized patients should be subjected to frequent monitoring of respiratory system function (chest radiography, PFT, microbiological analysis of opportunistic infections) and of the appearance of immunological abnormalities (measurement of immunologlobulin level, flow cytometric analysis of PBL subsets, etc.).

MG and infections in the course of thymoma before surgical treatment were diagnosed in only two patients (Table 1). Unfortunately, immunological system status (peripheral $\mathrm{T}$ and $\mathrm{B}$ cell repertoire as well as the levels of immunoglobulins) was not determined before our investigation. The patients had no stressful operations during observation. However, it is possible that thymectomy may finally trigger, but not actually cause, an outbreak of clinical symptoms.

An accurate and timely diagnosis of immunodeficiency associated with thymectomy is important in order to prevent further complications, which may result in irreversible lung tissue destruction. In the case of our patient with GS, treatment with intravenous immune globulin was effective. In the follow-up examination the patient maintained an $\mathrm{IgG}$ level above $550 \mathrm{mg} / \mathrm{dl}$, but IgA and IgM levels persisted below $10 \mathrm{mg} / \mathrm{dl}$.

The causes of immunodeficiency in patients with thymoma and in thymectomized subjects are still obscure. CD4 ${ }^{+}$T-lymphopenia and an inversion of the CD4:CD8 ratio have been found in GS patients with hypogammaglobulinemia and B-lymphopenia $[9,22]$. Hoffacker et al. [5] detected a significant increase in the proportion of circulating $\mathrm{CD} 45 \mathrm{RA}^{+} \mathrm{CD} 8^{+} \mathrm{T}$ cells in patients with thymoma and $\mathrm{MG}$ compared with healthy subjects. In contrast, the $\mathrm{CD}^{+}{ }^{+}$subset of $\mathrm{CD} 45 \mathrm{RA}^{+}$ $\mathrm{T}$ cells was not significantly altered in the blood of thymoma patients. The authors concluded that the increase in the proportion of CD45RA ${ }^{+} \mathrm{CD}^{+}$cells is due to the peripheralization of thymoma-derived mature $\mathrm{T}$ cells. They suggested that these $T$ cells contribute to the peripheral autoimmune cascade that leads to myasthenic symptoms of muscle weakness [5].

Strobel et al. [20] showed that the MG status of thymectomized patients was significantly associated with distinct abnormalities of intratumoral thymopoiesis. The percentage of mature naïve CD45RA ${ }^{+} \mathrm{CD} 4{ }^{+} \mathrm{T}$ cells was highly reduced in the blood of thymoma patients without MG. A statistically significant increase in the percentage of naïve $\mathrm{CD} 8^{+} \mathrm{T}$ cells was found in both MG-positive and MG-negative thymoma patients. Their results suggested that the spectrum of thymopoietic incompetence in thymomas may extend not only to the CD4, but also to the CD8 lineage [14, 20]. 
Table 5. Flow cytometry analysis of naïve $\mathrm{T}$ cell subsets in the examined groups

\begin{tabular}{lccc}
\hline & $\begin{array}{c}\text { Thymectomized } \\
\text { patients with MG }\end{array}$ & $\begin{array}{c}\text { Thymectomized } \\
\text { patients without MG }\end{array}$ & Control subjects \\
\hline $\begin{array}{l}\text { Percentage of } \\
\text { CD4 }{ }^{+} \text {cells with }\end{array}$ & $43.56 \pm 10.91$ & $32.55 \pm 14.29$ & $53.02 \pm 15.91$ \\
$\begin{array}{l}\text { CD45RA antigen } \\
\text { Percentage of }\end{array}$ & $86.32 \pm 7.64$ & $76.06 \pm 9.15$ & $81.30 \pm 9.92$ \\
$\begin{array}{l}\text { CD }{ }^{+} \text {cells with } \\
\text { CD45RA antigen }\end{array}$ & & & \\
\hline
\end{tabular}

Sempowski et al. [18] determined the effect of thymectomy in MG patients on the levels of peripheral blood cells containing signal joint TCR $\delta$ excision circles (TRECs), a molecular marker of recent thymic emigrants. The authors found that thymectomy resulted in a fall in TREC-positive $T$ cell concentrations when thymopoiesis was active at the time of surgery, but had little effect in patients when thymopoiesis was minimal. In contrast, naïve phenotype $\mathrm{T}$ cell levels did not fall after thymectomy, whereas memory phenotype $\mathrm{T}$ cell concentrations rose after thymectomy. The authors raised the hypothesis that the thymus is an endocrine organ, producing factors such as a leukemia-inhibitory factor and oncostatin $\mathrm{M}$ that may play roles in modulating peripheral blood $\mathrm{T}$ cell levels. An additional explanation for the lack of reduction in TREC-positive $\mathrm{T}$ cells after thymectomy in certain patients was the possibility that TREC-positive cells could be generated extrathymically [18]. This hypothesis may explain the role of thymic involution in healthy adults.

It is possible that autoreactive $\mathrm{T}$ cells in thymoma may also suppress the development of erythroid precursors in PRCA, and the maturation of eosinophils and B lymphocytes in immunodeficiency syndromes. The failure to produce B lymphocytes occurs at the stem cell level, as pre-B cells could not be found in the bone marrow in GS patients. The relationship between thymoma, $\mathrm{T}$ cell dysfunction, and abnormalities in hematopoietic stem cells remains conjectural, especially since thymectomy has little, if any, effect on the development of immunological disturbances and on the coexisting condition in patients with acquired immunodeficiency. Moreover, in some cases the symptoms manifested after removal of the thymoma $[1,4,6,16]$.

Our results confirmed the appearance of strong and general $\mathrm{T}$ cell immunological disturbance in patients after thymectomy. The mechanisms by which autoantigen-specific $\mathrm{T}$ cells contribute to the pathogenesis of paraneoplastic syndromes in patients after thymectomy are currently unknown. Our investigation may suggest the existence of an extrathymic center of thymopoiesis or residual ectopic thymic tissue in the neck that may not be excised during total thymectomy. In the first case, the lack of a correctly functioning thymus and the impairment of negative selection may be responsible for the survival of autoreactive clones of T lymphocytes.

In the light of this theory, the appearance of $\mathrm{CD} 4^{+} \mathrm{CD} 8^{+}$double-positive cells in the peripheral blood of some patients after thymectomy may be significant. Peripheral double-positive T cells could represent thymocytes that have prematurely escaped from the thymus [7]. This hypothesis may also be explained by the decrease in the percentage of T cells with CD28 antigen.

Matsui et al. [10] found a higher level of peripheral blood $\mathrm{CD} 4{ }^{+} \mathrm{CD} 8^{+}$double-positive cells in patients with MG and thymoma. The $\mathrm{CD}^{+}{ }^{+} \mathrm{CD} 8^{+} \mathrm{T}$ cell level was closely related to the clinical symptoms of $\mathrm{MG}$ within one year after thymectomy. The anti-AChR antibodies generally changed in parallel with the clinical state and level of $\mathrm{CD}^{+}{ }^{+} \mathrm{CD} 8^{+}$double-positive lymphocytes [10]. Nagvekar et al. [15] described $\mathrm{T}$ cell clones reacting against muscle acetylocholine receptors in MG with thymoma, and these clones expressed both CD4 and $\mathrm{CD} 8 \alpha$ antigens and had a $\mathrm{Th}_{0}$ cytokine profile, producing IL-4 and IFN- $\gamma$.

$\mathrm{T}$ cells from CD28-deficient mice had strongly impaired proliferation in vitro after stimulation with antibodies to the TCR. Similarly in vivo, CD28-deficient mice exhibited impaired Th $\mathrm{B}$ cell responses, although $\mathrm{CD} 8^{+}$cytotoxic T-lymphocyte induction appeared to be normal. An abnormal humoral response in developing this mechanism may explain the existence of immunodeficiency in GS patients [2, 19].

The existence of $\mathrm{CD} 4{ }^{+} \mathrm{CD} 8{ }^{+}$double-positive cells in the peripheral blood after surgical removal of the thymus may also result from the abnormal maturation of cells and the lack of elimination of immature lymphocytes in the thymus. The impairment of the thymus in thymectomized patients seems to be connected with the decrease in the percentage of T cells with CD28 antigen. The question arises whether the hypothesis concerning the development of autoreactive clones of $\mathrm{T}$ lymphocytes in thymoma is valid. We suggest that the disorganized thymic cortical environment in thymoma, as well as the absence of the thymus after thymectomy, might merely fail to delete or tolerate potentially self-reactive $\mathrm{T}$ cells. This may result in a condition where, in a patient with a non-totally disorganized thymus, the symptoms of immunological abnormalities do not manifest themselves and only appear after thymectomy. This also indicates a possible, and perhaps dominant, role of the thymus in autoreactive cell elimination in adults.

Acknowledgment: This study was supported by the Polish State Committee for Scientific Research (KBN) grant no. 3P0 5B 05124. 


\section{REFERENCES}

1. Arend S. M., Dik H. and van Dissel J. T. (2001): Good's syndrome: the association of thymoma and hypogammaglobulinemia. Clin. Infect. Dis., 32, 323-325.

2. Coyle A. J. and Gutierrez-Ramos J. C. (2001): The expanding B7 superfamily: Increasing complexity in costimulatory signals regulating $\mathrm{T}$ cell function. Nat. Immunol. 2, 203-207.

3. Good R. A. (1954): Agammaglobunemia: a provocative experiment of nature. Bull. Univ. Minn. Hosp. Med. Found., 26, 1-19.

4. Hayward A. R., Paolucci P., Webster A. D. and Kohler P. (1982): Pre-B cell suppression by thymoma patient lymphocytes. Clin. Exp. Immunol., 48, 437-442.

5. Hoffacker V., Schultz A., Tiesinga J. J., Gold R., Schalke B., Nix W., Kiefer R., Muller-Hermelink H. K. and Marx A. (2000): Thymomas alter the T-cell subset composition in the blood: a potential mechanism for thymoma-associated autoimmune disease. Blood, 96, 3872-3879.

6. Ito Y., Kuriyama Y., Tauchi T., Ohyashiki J. H., Toyama K. and Ohyashiki K. (1999): A patient with pure red cell aplasia and Good's syndrome. Haematologica, 84, 1048-1049.

7. Jimenez E., Sacedon R., Vicente A., Hernandez-Lopez C., Zapata A. G. and Varas A. (2002): Rat peripheral CD4+CD8+ T lymphocytes are partially immunocompetent thymus-derived cells that undergo post-thymic maturation to become functionally mature $\mathrm{CD} 4+\mathrm{T}$ lymphocytes. J. Immunol., 168, 5005-5013.

8. Loehrer P. J. Sr. and Wick M. R. (2000): Thymic malignancies. Cancer Treat. Res., 105, 277-302.

9. Masci A. M., Palmieri G., Perna F., Montella L., Merkabaoui G., Sacerdoti G., Martignetti A. and Racioppi L. (1999): Immunological findings in thymoma and thymoma-related syndromes. Ann. Med., 31 (suppl. 2), 86-89.

10. Matsui M., Fukuyama H., Akiguchi I. and Kameyama M. (1989): Circulating CD4+CD8+ cells in myasthenia gravis: supplementary immunological parameter for long-term prognosis. J. Neurol., 236, 329-335.

11. Miller J. F. (2002): The discovery of thymus function and thymus derived lymphocytes. Immunol. Rev., 185, 7-14.

12. Mizobuchi S., Yamashiro T., Nonami Y., Yamamoto A.,
Kume M., Nakaya H., Sawada T., Taguchi H., Moriki T. and Ogoshi S. (1998): Pure red cell aplasia and myasthenia gravis with thymoma: a case report and review of the literature. Jap. J. Clin. Oncol., 28, 696-701.

13. Moysset I., Lloreta J., Miguel A., Vadell C., Ribalta T., Estrach T. and Serrano S. (1997): Thymoma associated with CD4+ lymphopenia, cytomegalovirus infection, and Kaposi's sarcoma. Hum. Pathol., 28, 1211-1213.

14. Muller-Hermelink H. K. and Marx A. (1999): Pathological aspects of malignant and benign thymic disorders. Ann. Med., 31 (suppl. 2), 5-14.

15. Nagvekar N., Moody A. M., Moss P., Roxains I. and Wilcox N. (1998): A pathogenic role for the thymoma in myasthenia gravis. J. Clin. Ivest., 101, 2268-2277.

16. Raschal S., Siegel J. N., Huml J. and Richmond G. W. (1997): Hypogammaglobulinemia and anemia 18 years after thymoma resection. J. Allergy Clin. Immunol., 100, 846-848.

17. Rothenberg E. V. and Dionne C. J. (2002): Lineage plasticity and commitment in T-cell development. Immunol. Rev., 185, 96-115.

18. Sempowski G. D., Thomasch J. R., Gooding M. E., Hale L. P., Edwards L. J., Ciafaloni E., Sanders D. B., Massey J. M., Douek D., Koup R. A. and Haynes B. F. (2001): Effect of thymectomy on human peripheral blood $\mathrm{T}$ cell pools in myasthenia gravis. J. Immunol., 166, 2808-2817.

19. Sharpe A. H. and Freeman G. J. (2002): The B7-CD128 Superfamily. Nat. Rev. Immunol., 2, 116-126.

20. Strobel P., Helmreich M., Menioudakis G., Lewin S. R., Rudiger T., Bauer A., Hoffacker V., Gold R., Nix W., Schalke B., Elert O., Semik M., Muller-Hermelink H. K. and Marx A. (2002): Paraneoplastic myasthenia gravis correlates with generation of mature naive CD4(+) T cells in thymomas. Blood, 100, 159-166.

21. Strollo D. C. and Rosado de Christenson M. L. and Jett J. R. (1997): Primary mediastinal tumors. Part 1 . Tumors of the anterior mediastinum. Chest, 112, 511-522.

22. Tarr P. E., Sneller M. C., Mechanic L. J., Economides A., Eger C. M., Strober W., Cunningham-Rundles C. and Lucey D. R. (2001): Infections in patients with immunodeficiency with thymoma (Good syndrome). Report of 5 cases and review of the literature. Medicine (Baltimore), 80, 123-133. 